\title{
A prospective cohort study on dietary acrylamide intake and the risk for cutaneous malignant melanoma
}

Citation for published version (APA):

Lipunova, N., Schouten, L. J., van den Brandt, P. A., \& Hogervorst, J. G. F. (2017). A prospective cohort study on dietary acrylamide intake and the risk for cutaneous malignant melanoma. European Journal of Cancer Prevention, 26(6), 528-531. https://doi.org/10.1097/CEJ.0000000000000268

Document status and date:

Published: 01/11/2017

DOI:

10.1097/CEJ.0000000000000268

Document Version:

Publisher's PDF, also known as Version of record

Document license:

Taverne

Please check the document version of this publication:

- A submitted manuscript is the version of the article upon submission and before peer-review. There can be important differences between the submitted version and the official published version of record.

People interested in the research are advised to contact the author for the final version of the publication, or visit the DOI to the publisher's website.

- The final author version and the galley proof are versions of the publication after peer review.

- The final published version features the final layout of the paper including the volume, issue and page numbers.

Link to publication

\footnotetext{
General rights rights.

- You may freely distribute the URL identifying the publication in the public portal. please follow below link for the End User Agreement:

www.umlib.nl/taverne-license

Take down policy

If you believe that this document breaches copyright please contact us at:

repository@maastrichtuniversity.nl

providing details and we will investigate your claim.
}

Copyright and moral rights for the publications made accessible in the public portal are retained by the authors and/or other copyright owners and it is a condition of accessing publications that users recognise and abide by the legal requirements associated with these

- Users may download and print one copy of any publication from the public portal for the purpose of private study or research.

- You may not further distribute the material or use it for any profit-making activity or commercial gain

If the publication is distributed under the terms of Article $25 \mathrm{fa}$ of the Dutch Copyright Act, indicated by the "Taverne" license above, 


\section{A prospective cohort study on dietary acrylamide intake and the risk for cutaneous malignant melanoma Nadezda Lipunova ${ }^{\mathrm{a}}$, Leo J. Schouten
Janneke ${ }^{\mathrm{a}}$, Piet A. . van den Brandt ${ }^{\mathrm{a}}$ and}

Epidemiological studies have shown inconsistent associations between dietary acrylamide exposure and the risk for various malignancies. This is the first epidemiological study on the association between acrylamide intake and the risk for cutaneous malignant melanoma (CMM). A case-cohort analysis was carried out within the prospective Netherlands Cohort Study on diet and cancer. Acrylamide intake was estimated from a food frequency questionnaire combined with acrylamide data for Dutch foods. After 17.3 years of follow-up, 501 microscopically confirmed cases of CMM were identified. There was an increased risk for CMM when dietary acrylamide was modeled as a continuous variable [hazard ratio: 1.13 (95\% confidence interval: $1.01-1.26)]$ per $10 \mu \mathrm{g}$ increment among men but there was no clear linear trend over the quintiles $\left(P_{\text {trend }}=0.12\right)$. No associations were observed for women. Our study provides some indications

\section{Introduction}

Acrylamide is classified as a probable human carcinogen based on its observed carcinogenicity in rodent studies (Pelucchi et al., 2015). Acrylamide forms in heat-treated starchy foods, such as coffee, French fries, and cookies (Pelucchi et al., 2015).

Results from epidemiological studies indicate that dietary acrylamide might be associated with the risk for kidney, endometrial, and ovarian cancers but the results were inconsistent (Pelucchi et al., 2015). Every tissue is a potential target for acrylamide-induced carcinogenesis because acrylamide is distributed throughout the whole body.

Our objective was to investigate, for the first time, the association between dietary acrylamide intake and the risk for cutaneous malignant melanoma (CMM).

\section{Materials and methods}

The association between acrylamide intake and CMM risk was investigated in the Netherlands Cohort Study on diet and cancer (NLCS) (van den Brandt et al., 1990), a case-cohort study. CMM cases from the whole cohort were identified during follow-up, and a random sample of 5000 men and women sampled at baseline served as a subcohort from which accumulated person-years for the

Supplemental digital content is available for this article. Direct URL citations appear in the printed text and are provided in the HTML and PDF versions of this article on the journal's website (www.eurjcancerprev.com).

\author{
that dietary acrylamide may increase the risk for CMM \\ in men. European Journal of Cancer Prevention 26:528-531 \\ Copyright (c) 2017 Wolters Kluwer Health, Inc. All rights \\ reserved.
}

European Journal of Cancer Prevention 2017, 26:528-531

Keywords: cutaneous malignant melanoma, dietary acrylamide, prospective cohort study

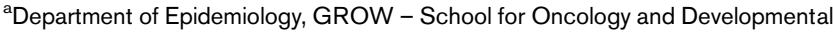
Biology, Maastricht University Medical Center +, Maastricht, The Netherlands and ${ }^{b}$ Department of Environmental Biology, Center for Environmental Sciences, Hasselt University, Diepenbeek, Belgium

Correspondence to Janneke G.F. Hogervorst, PhD, Center for Environmental Sciences, Hasselt University, Agoralaan gebouw D, 3590 Diepenbeek, Belgium Tel: + 3211 268224; fax: + 3211268301 ;

e-mail: janneke.hogervorst@uhasselt.be

Received 9 February 2016 Accepted 6 April 2016

entire cohort (120852 participants) were estimated. There were 1951 male subcohort members and 224 male CMM cases, and 2101 female subcohort members and 224 female CMM cases available for analysis (Supplemental Fig. 1, Supplemental digital content 1, http://links.lww.com/EJCP/A66).

Histologically confirmed CMM cases were identified through linkage with the Dutch Pathology Registry (PALGA) and the National Dutch Cancer Registry. Completeness of follow-up of these registries is estimated to be at least $96 \%$ (Schouten et al., 1993). Follow-up for vital status in the NLCS, as assessed through linkage with the Municipal Personal Records Database (GBA), at the end of the follow-up period (17.3 years) was nearly $100 \%$; only one male subcohort member was lost to follow-up.

The NLCS has been approved by the Medical Ethics Committee of Maastricht University (Maastricht, the Netherlands).

Acrylamide intake was assessed using a self-administered food frequency questionnaire (FFQ) on 150 food items, and from this FFQ acrylamide intake was estimated as described elsewhere (Hogervorst et al., 2007).

The NLCS questionnaire did not contain direct questions on UV exposure. To adjust for nonoccupational UV exposure, proxies using open-ended questions on hobbies and sports were constructed. The women's version of the NLCS 
questionnaire did not contain a question concerning hobbies, and hence for women we only constructed a proxy based on sports. A maximum of three hobbies and sports could be entered by the participants. Three variables were created for UV exposure through hobbies and three similar variables for UV exposure through sports: exposure to UV of limbs only (men and women combined) and exposure to UV of both limbs and trunk (sex-specific). Variables were coded as 1 (exposure to UV likely) and 0 (exposure to UV unlikely) (Supplemental Table 1, Supplemental digital content 2, http://links.lww.com/EJCP/A67 and 2, Supplemental digital content 3, http://links.lww.com/EJCP/A68). Coding was carried out independently by two researchers (N.L. and J.G.F.H.). Divergent codings were discussed until consensus was reached. To adjust for occupational UV exposure, information from the Finnish job-exposure matrix (FINJEM) was used (Kauppinen et al., 2009). Exposure estimates in FINJEM are provided for the period between 1960 and 2003 and are presented as a proportion of workers exposed $(P)$ multiplied by the level of exposure $(L)$. Job codes assigned in the NLCS based on data on occupation were translated into those compatible with FINJEM (Koeman et al., 2013).

Hazard ratios (HR) were obtained using Cox proportional hazards models for men and women separately. SEs were estimated using the robust Huber-White sandwich estimator. The proportional hazards assumption was tested using scaled Schoenfeld residuals. HRs were adjusted for covariables: age, smoking status, smoking frequency and duration, body mass index, and education level. The proxies for UV exposure did not change the HRs of acrylamide and were therefore not included in the models.

Subgroup analyses were carried out separately for histological subtypes [nodular (NM) and superficial spreading melanoma (SSM)] and for never-smokers (or for men: never-smokers and those who quit smoking at least 10 years before baseline) because smoking causes substantial acrylamide exposure (Hagmar et al., 2005).

A result was considered statistically significant if the $P$-value was 0.05 or less (two sided). STATA software (StataCorp 2011, Stata Statistical Software: Release 12; StataCorp LP, College Station, Texas, USA) was used for all statistical analyses.

\section{Results}

For most variables there were no striking differences between CMM, NM, and SSM cases and subcohort members (Table 1). However, cases were more highly

Table 1 Characteristics of total cutaneous malignant, superficial spreading, and nodular melanoma cases and subcohort members: the Netherlands cohort study on diet and cancer, 1986-2003 ${ }^{\mathrm{a}, \mathrm{b}}$

\begin{tabular}{|c|c|c|c|c|c|c|c|c|}
\hline & \multicolumn{4}{|c|}{ Men } & \multicolumn{4}{|c|}{ Women } \\
\hline & Subcohort & CMM & SSM & NM & Subcohort & CMM & SSM & NM \\
\hline$N$ & 2191 & 241 & 94 & 40 & 2247 & 236 & 102 & 30 \\
\hline Acrylamide ( $\mu \mathrm{g} /$ day) & $22.6(12.2)$ & $23.9(13)$ & $24.1(12.4)$ & $27.5(15.4)$ & $21.1(11.9)$ & $21.2(11.7)$ & $20.5(10.9)$ & $21.5(12.6)$ \\
\hline Age (years) & $61.3(4.2)$ & $61.7(4.3)$ & $61.2(4.3)$ & $62.8(4.5)$ & $61.4(4.3)$ & $61.9(4.1)$ & $61.6(4.1)$ & $61.4(4.2)$ \\
\hline BMI $\left(\mathrm{kg} / \mathrm{m}^{2}\right)$ & $25(2.6)$ & $25.4(2.7)$ & $25.3(3)$ & $25.1(2.1)$ & $25.1(3.6)$ & $24.8(3.4)$ & $24.5(3.1)$ & $25.0(4.3)$ \\
\hline \multicolumn{9}{|l|}{ Smoking status (\%) } \\
\hline Never-smokers & 12.7 & 17.8 & 20.2 & 12.5 & 58.4 & 54.2 & 53.9 & 50 \\
\hline Former smokers & 51.6 & 59.8 & 59.6 & 65 & 20.6 & 28 & 32.4 & 26.7 \\
\hline Current smokers & 35.7 & 22.4 & 20.2 & 22.5 & 21 & 17.8 & 13.7 & 23.3 \\
\hline Smoking [years (former and current smokers only)] & $33.7(11.8)$ & $29.8(13)$ & $28.4(13.8)$ & $30.9(12.7)$ & $27.8(12.5)$ & $26.8(12.4)$ & $25.7(12.4)$ & $25.7(13)$ \\
\hline $\begin{array}{l}\text { Smoking [cigarettes/day (former and current smokers } \\
\text { only)] }\end{array}$ & $17(10.6)$ & $15(10.5)$ & $14.4(9.3)$ & $17.2(12.1)$ & $11.4(8.3)$ & $12.2(11.2)$ & $12.7(9.5)$ & $19.2(20.2)$ \\
\hline \multicolumn{9}{|l|}{ Education $(\%)$} \\
\hline Primary school & 25 & 16.6 & 13.8 & 15 & 33.5 & 27.7 & 26.7 & 23.3 \\
\hline Lower vocational school & 20.7 & 13.7 & 11.7 & 7.5 & 23.2 & 23.4 & 25.7 & 16.7 \\
\hline Intermediate vocational school/high school & 35.6 & 4.7 & 42.6 & 50 & 34.5 & 37 & 36.6 & 46.7 \\
\hline Higher vocational school/university & 18.7 & 29.1 & 31.9 & 27.5 & 8.8 & 11.9 & 10.9 & 13.3 \\
\hline \multicolumn{9}{|l|}{ Occupational UV exposure (\%) } \\
\hline Never & 72.9 & 78.0 & 77.7 & 80.0 & 97 & 95.8 & 97.1 & 90 \\
\hline Ever & 12.8 & 10.4 & 11.7 & 10.0 & 1.5 & 2.5 & 0.0 & 0.0 \\
\hline High & 14.3 & 11.6 & 10.6 & 10.0 & 1.5 & 1.7 & 2.9 & 10.0 \\
\hline Cumulative exposure $(P \times L / 100)$ & $761(1951)$ & $673(1770)$ & $697(1708)$ & $434(1234)$ & $57.3(472)$ & $80.1(589)$ & $126(820)$ & $36.0(121)$ \\
\hline \multicolumn{9}{|l|}{ Nonoccupational UV exposure to the limbs from (\%) } \\
\hline Hobbies (yes) & 41.5 & 36.5 & 35.1 & 42.5 & c & c & c & c \\
\hline Sports (yes) & 45.1 & 49.8 & 45.4 & 55.0 & 23.1 & 27.5 & 26.5 & 40.0 \\
\hline \multicolumn{9}{|c|}{ Nonoccupational UV exposure to the limbs and trunk from (\%) } \\
\hline Hobbies (yes) & 30.8 & 27.8 & 29.8 & 22.5 & c & c & c & c \\
\hline Sports (yes) & 16.0 & 18.3 & 18.1 & 20.0 & 16.6 & 22.5 & 20.6 & 30.0 \\
\hline
\end{tabular}

$P$, prevalence of exposure (\%); $L$, level of exposure $\left(\mathrm{J} / \mathrm{m}^{2}\right)$ (Kauppinen et al., 2009).

CMM, cutaneous malignant melanoma; NM, nodular melanoma; NLCS, the Netherlands cohort study on diet and cancer; SSM, superficial spreading melanoma.

aData represent means (SD), or percentages unless otherwise indicated; $n$ represents number of subcohort members or cases after exclusion of participants with prevalent cancer at baseline and/or with incomplete or inconsistent dietary data.

${ }^{b}$ The number of missing values varies.

${ }^{\mathrm{c}}$ The NLCS questionnaire contained a question on hobbies for men only. 
Table 2 Association between dietary acrylamide intake and cutaneous malignant melanoma in men and women: the Netherlands cohort study on diet and cancer, 1986-2003

\begin{tabular}{|c|c|c|c|c|c|c|c|c|}
\hline & \multicolumn{4}{|c|}{ Overall } & \multicolumn{4}{|c|}{ Never-cigarette-smokers and 10-year quitters of cigarette smoking } \\
\hline & $N$ (cases) & $N$ (person years) & $\mathrm{HR}(95 \% \mathrm{Cl})^{\mathrm{a}}$ & $\operatorname{HR}(95 \% \mathrm{Cl})^{\mathrm{b}}$ & $N$ (cases) & $N$ (person years) & $\mathrm{HR}(95 \% \mathrm{Cl})^{\mathrm{a}}$ & $\operatorname{HR}(95 \% \mathrm{Cl})^{\mathrm{c}}$ \\
\hline \multicolumn{9}{|c|}{ Men } \\
\hline \multicolumn{9}{|c|}{ Total cutaneous malignant melanoma } \\
\hline AA $(10 \mu \mathrm{g} /$ day $)$ & 224 & 28124 & $1.10(0.99-1.22)$ & $1.13(1.01-1.26)$ & 136 & 13340 & $1.04(0.90-1.20)$ & $1.07(0.92-1.26)$ \\
\hline Q1 & 45 & 5625 & Reference & Reference & 32 & 2870 & Reference & Reference \\
\hline Q2 & 46 & 5435 & $1.08(0.70-1.67)$ & $1.14(0.73-1.80)$ & 28 & 2675 & $0.96(0.55-1.67)$ & $0.99(0.55-1.77)$ \\
\hline Q3 & 35 & 5734 & $0.81(0.51-1.30)$ & $0.90(0.55-1.45)$ & 21 & 2383 & $0.82(0.45-1.50)$ & $0.85(0.46-1.58)$ \\
\hline Q4 & 38 & 5609 & $0.91(0.57-1.44)$ & $1.03(0.64-1.66)$ & 22 & 2482 & $0.83(0.46-1.49)$ & $0.89(0.48-1.64)$ \\
\hline Q5 & 60 & 5721 & $1.37(0.90-2.07)$ & $1.52(0.98-2.33)$ & 33 & 2930 & $1.03(0.60-1.77)$ & $1.13(0.63-2.00)$ \\
\hline$P_{\text {trend }}{ }^{d}$ & & & 0.29 & 0.12 & & & 0.94 & 0.81 \\
\hline \multicolumn{9}{|l|}{ Nodular melanoma } \\
\hline AA $(10 \mu \mathrm{g} /$ day $)$ & 39 & 28124 & $1.27(1.07-1.51)$ & $1.36(1.11-1.67)$ & 25 & 13340 & $1.37(1.11-1.69)$ & $1.60(1.19-2.15)$ \\
\hline \multicolumn{9}{|c|}{ Superficial spreading melanoma } \\
\hline AA $(10 \mu \mathrm{g} /$ day $)$ & 86 & 28124 & $1.10(0.94-1.28)$ & $1.14(0.97-1.34)$ & 54 & 13340 & $0.92(0.74-1.13)$ & $0.94(0.75-1.18)$ \\
\hline Q1 & 14 & 5877 & Reference & Reference & 20 & 4122 & - & - \\
\hline Q2 & 23 & 6829 & $0.96(0.51-1.81)$ & $1.02(0.53-1.95)$ & 19 & 4457 & - & - \\
\hline Q3 & 23 & 8228 & $1.10(0.59-2.05)$ & $1.26(0.66-2.40)$ & 15 & 4762 & - & - \\
\hline Q4 & 26 & 7189 & $1.26(0.69-2.31)$ & $1.42(0.77-2.64)^{\dagger}$ & - & - & - & - \\
\hline \multirow[t]{3}{*}{$P_{\text {trend }}{ }^{d}$} & & & 0.40 & 0.21 & & & & \\
\hline & \multicolumn{4}{|c|}{ Overall } & \multicolumn{4}{|c|}{ Never cigarette-smokers } \\
\hline & $n$ (cases) & $n$ (person years) & $\operatorname{HR}(95 \% \mathrm{Cl})^{\mathrm{a}}$ & $\mathrm{HR}(95 \% \mathrm{Cl})^{\mathrm{b}}$ & $n$ (cases) & $n$ (person years) & $\operatorname{HR}(95 \% \mathrm{Cl})^{\mathrm{a}}$ & $\operatorname{HR}(95 \% \mathrm{Cl})^{\mathrm{e}}$ \\
\hline \multicolumn{9}{|c|}{ Women } \\
\hline \multicolumn{9}{|c|}{ Total cutaneous malignant melanoma } \\
\hline AA $(10 \mu \mathrm{g} /$ day $)$ & 224 & 32990 & $0.97(0.87-1.09)$ & $0.97(0.86-1.08)$ & 123 & 19939 & $1.03(0.88-1.20)$ & $1.02(0.88-1.20)$ \\
\hline Q1 & 43 & 6433 & Reference & Reference & 21 & 4238 & Reference & Reference \\
\hline Q2 & 47 & 6695 & $1.08(0.70-1.67)$ & $1.10(0.71-1.72)$ & 27 & 4060 & $1.37(0.75-2.48)$ & $1.39(0.76-2.56)$ \\
\hline Q3 & 48 & 6354 & $1.19(0.77-1.84)$ & $1.25(0.80-1.96)$ & 28 & 3561 & $1.74(0.96-3.15)$ & $1.78(0.96-3.30)$ \\
\hline Q4 & 47 & 6857 & $1.07(0.69-1.66)$ & $1.11(0.71-1.73)$ & 25 & 4107 & $1.30(0.71-2.39)$ & $1.31(0.71-2.43)$ \\
\hline Q5 & 39 & 6650 & $0.91(0.58-1.43)$ & $0.91(0.57-1.44)$ & 22 & 3972 & $1.16(0.62-2.15)$ & $1.16(0.62-2.19)$ \\
\hline$P_{\text {trend }}{ }^{\mathrm{d}}$ & & & 0.70 & 0.71 & & & 0.72 & 0.74 \\
\hline \multicolumn{9}{|l|}{ Nodular melanoma } \\
\hline AA $(10 \mu \mathrm{g} /$ day $)$ & 29 & 32990 & $0.94(0.68-1.29)$ & $0.92(0.68-1.25)$ & 14 & 19939 & - & - \\
\hline \multicolumn{9}{|c|}{ Superficial spreading melanoma } \\
\hline AA $(10 \mu \mathrm{g} /$ day $)$ & 94 & 32990 & $0.92(0.77-1.10)$ & $0.91(0.76-1.08)$ & 52 & 19939 & $0.95(0.76-1.19)$ & $0.94(0.75-1.19)$ \\
\hline Q1 & 26 & 9424 & Reference & Reference & 22 & 7828 & - & - \\
\hline Q2 & 28 & 8405 & $1.25(0.72-2.20)$ & $1.30(0.73-2.31)$ & 18 & 5816 & - & - \\
\hline Q3 & 23 & 7077 & $1.11(0.62-1.99)$ & $1.16(0.64-2.09)$ & 12 & 6295 & - & - \\
\hline Q4 & 17 & 8084 & $0.73(0.39-1.37)$ & $0.71(0.37-1.35)$ & - & - & - & - \\
\hline$P_{\text {trend }}{ }^{d}$ & & & 0.27 & 0.25 & & & & \\
\hline
\end{tabular}

The median acrylamide intake of the male subcohort in the quintiles was $10.8,15.6,19.6,25.4$, and $37.6 \mu$ g/day. The median acrylamide intake of the female subcohort in the quintiles was $9.5,14.0,17.9,24.3$, and $36.8 \mu \mathrm{g} /$ day.

-, Too few cases to carry out the analysis; $95 \% \mathrm{Cl}, 95 \%$ confidence interval; HR, hazard ratio.

adjusted for age.

${ }^{\mathrm{b}}$ Adjusted for age, education level (primary school, lower vocational school, intermediate vocational/high school, higher vocational school/university), BMI (kg/m²), cigarette smoking status (never/former/current smokers), number of cigarettes smoked per day, number of years of smoking cigarettes.

${ }^{\mathrm{c}}$ Adjusted for age, education level (primary school, lower vocational school, intermediate vocational/high school, higher vocational school/university), BMI (kg/m²), number of cigarettes smoked per day, number of years of smoking cigarettes.

d The $P$-value for trend was calculated by modeling the median acrylamide intake value in each quantile as a continous variable.

${ }^{\mathrm{e}}$ Adjusted for age, education level (primary school, lower vocational school, intermediate vocational/high school, higher vocational school/university), BMI (kg/m ${ }^{2}$ ).

fProportional hazards assumption was violated.

educated than subcohort members, whereas smoking was more prevalent among subcohort members.

There was a statistically significant positive multivariableadjusted association between acrylamide intake modeled per $10 \mu \mathrm{g} /$ day increment and total CMM risk among men [HR 1.13 (95\% CI: 1.01-1.26)] (Table 2). The quintile analysis, however, did not reflect a linear dose-response relationship ( $P_{\text {trend }}: 0.12$ ). The association was less strong in nonsmoking men, with an HR of 1.07 (95\% CI: $0.92-1.26)$ per $10 \mu \mathrm{g}$ acrylamide increment.
Subtype analyses showed a statistically significant positive association between dietary acrylamide and the risk for NM among men [HR 1.36 (95\% CI: 1.11-1.67)] per $10 \mu \mathrm{g}$ acrylamide increment (Table 2). A stronger association was seen among nonsmoking men [HR 1.60 (95\% CI: 1.19-2.15)]. No statistically significant associations were observed between dietary acrylamide intake and the risk for SSM among men. The proportional hazards assumption was violated in the highest quartile of dietary acrylamide intake in the analysis of SMM but no statistically significant interaction with time was observed. 
Among women, there was no association between acrylamide intake and melanoma risk (Table 2).

\section{Discussion}

This study provides some indications that dietary acrylamide may increase the risk for overall CMM and NM among men. There was no positive association with total CMM risk in the group of nonsmoking men. For NM, however, the association between dietary acrylamide intake and NM risk was stronger in nonsmoking men. The latter finding may be spurious because of the small number of cases. No association was observed for SSM. No statistically significant associations were observed among women.

Differences in biological mechanisms in the etiology of different histological CMM subtypes are still unclear (Whiteman et al., 2011) but it is possible that acrylamide has a differential effect on different subtypes. Acrylamide has been previously shown to cause genotoxicity and to influence sex hormone levels in rodents (Besaratinia and Pfeifer, 2007). Although melanoma is not clearly a sex hormone-dependent cancer, it is likely that sex hormones are of importance in melanomagenesis (de Giorgi et al., 2011) and their role may differ in men and women. Smoking influences sex hormone levels, which may explain the differential associations between acrylamide intake and melanoma risk based on smoking status.

Our study has a few limitations. FFQs have limitations with regard to assessing dietary acrylamide exposure (Hogervorst et al., 2007). Nondifferential measurement error of the acrylamide intake resulting from the use of an FFQ in a prospective cohort study will push the risk estimate toward null. In addition, subgroup analyses were carried out with relatively small numbers. Therefore, the results have to be interpreted with caution. Proxies of sun exposure to the trunk and lower limbs due to hobbies and sports or occupational UV exposure were no confounders of the association between dietary acrylamide and the risk for CMM. In addition, the observation of similar risk estimates for different anatomical locations of CMM (results not shown) also suggests that UV exposure is not a confounder because anatomical location is a surrogate for assessing sun exposure patterns. All in all, it is unlikely that UV exposure was a confounder in this analysis but residual confounding cannot be ruled out.

Important strengths of the study are its prospective nature, large study size, and virtually no loss to follow-up.
In conclusion, our study gives some indications for a positive association between dietary acrylamide and the risk for total CMM and NM among men and no association among women.

\section{Acknowledgements}

The authors thank Nadine Offermans (formerly from the Department of Epidemiology, GROW - School for Oncology and Developmental Biology, Maastricht, the Netherlands) and Timo Kauppinen from the Department of Occupational Health, Finnish Institute of Occupational Health, Helsinki, Finland, for assistance using the Finnish job exposure matrix (FINJEM).

The NLCS was established with funding from the Dutch Cancer Society. Dietary acrylamide analyses were funded by the Dutch Food and Consumer Product Safety Authority (nVWA).

\section{Conflicts of interest}

There are no conflicts of interest.

\section{References}

Besaratinia A, Pfeifer GP (2007). A review of mechanisms of acrylamide carcinogenicity. Carcinogenesis 28:519-528.

de Giorgi V, Sestini S, Gori A, Mazzotta C, Grazzini M, Rossari S, et al. (2011). Polymorphisms of estrogen receptors: risk factors for invasive melanoma - a prospective study. Oncology 80 (3-4):232-237.

Hagmar L, Wirfalt E, Paulsson B, Tornqvist M (2005). Differences in hemoglobin adduct levels of acrylamide in the general population with respect to dietary intake, smoking habits and gender. Mutat Res 580 (1-2):157-165.

Hogervorst JG, Schouten LJ, Konings EJ, Goldbohm RA, van den Brandt PA (2007). A prospective study of dietary acrylamide intake and the risk of endometrial, ovarian, and breast cancer. Cancer Epidemiol Biomarkers Prev 16:2304-2313.

Kauppinen T, Heikkila P, Plato N, Wlodbaek T, Lenvik K, Hansen J, et al. (2009). Construction of job-exposure matrices for the Nordic Occupational Cancer Study (NOCCA). Acta Oncol 48:791-800.

Koeman T, Offermans NS, Christopher-de Vries Y, Slottje P, van den Brandt PA, Alexandra Goldbohm R, et al. (2013). JEMs and incompatible occupational coding systems: effect of manual and automatic recoding of job codes on exposure assignment. Ann Occup Hyg 57:107-114.

Pelucchi C, Bosetti C, Galeone C, La Vecchia C (2015). Dietary acrylamide and cancer risk: an updated meta-analysis. Int J Cancer 136:2912-2922.

Schouten LJ, Hoppener P, van den Brandt PA, Knottnerus JA, Jager JJ (1993). Completeness of cancer registration in Limburg, the Netherlands. Int $J$ Epidemiol 22:369-376.

van den Brandt PA, Goldbohm RA, van't Veer P, Volovics A, Hermus RJ, Sturmans F (1990). A large-scale prospective cohort study on diet and cancer in the Netherlands. J Clin Epidemio/ 43:285-295.

Whiteman DC, Pavan WJ, Bastian BC (2011). The melanomas: a synthesis of epidemiological, clinical, histopathological, genetic, and biological aspects, supporting distinct subtypes, causal pathways, and cells of origin. Pigment Cell Melanoma Res 24:879-897. 